\title{
A preliminary study on estimating extra-cellular nitrate reductase activities in estuarine systems
}

\author{
H.K. Pant ${ }^{(1)}$ \\ Received March 1st, 2009 / Reçu le $1^{\mathrm{er}}$ mars 2009 \\ Revised June 10, 2009 / Révisé le 10 juin 2009 \\ Accepted June 15, 2009 / Accepté le 15 juin 2009
}

Key-words:

nitrate

reductase, estuarinewaters, water quality, nitrous oxide

\section{ABSTRACT}

Enzymes catalyzing ammonium $\left(\mathrm{NH}_{4}{ }^{+}\right) /$nitrate $\left(\mathrm{NO}_{3}{ }^{-}\right)$into nitrous oxide $\left(\mathrm{N}_{2} \mathrm{O}\right)$ /molecular nitrogen $\left(\mathrm{N}_{2}\right)$, play critical roles in water quality management. The objective of this paper was to investigate the role of extra-cellular enzymes in cycling of nitrogen $(\mathrm{N})$ in aquatic systems. It appears that $\mathrm{N}$ in estuaries, salt marshes, etc., does not stay long enough to be available for uptake, thus, creating $\mathrm{N}$ limited conditions. This study showed that indigenous extra-cellular nitrate reductase along with others involved in $\mathrm{N}$ transformations in the waters/sediments of estuarine systems can cause complete removal of $\mathrm{NH}_{4}{ }^{+}$and $\mathrm{NO}_{3}{ }^{-}$from the waters and available $\mathrm{NH}_{4}{ }^{+}$ and $\mathrm{NO}_{3}{ }^{-}$from the sediments. These results indicate that due to high extracellular nitrate reductase and other enzymes associated with $\mathrm{N}$ transformations in sediments/waters, substantial amounts of $\mathrm{NH}_{4}{ }^{+}$and $\mathrm{NO}_{3}{ }^{-}$can be quickly lost from the systems as $\mathrm{N}_{2} \mathrm{O}$ and/or nitric oxide (NO), in turn, creating $\mathrm{N}$ limited conditions in estuarine systems. Such high activities of indigenous nitrate reductase and others are useful in removing readily bioavailable $\mathrm{N}$ from the systems, thereby avoidance of eutrophic conditions. However, they might contribute in increasing the $\mathrm{N}_{2} \mathrm{O}$, a potent greenhouse gas with global warming potential (GWP) of 296, in the atmosphere.

\section{RÉSUMÉ}

Une étude préliminaire d'estimation des activités nitrate réductase dans des systèmes estuariens

Mots-clés : Les enzymes catalysant les réactions ammonium $\left(\mathrm{NH}_{4}{ }^{+}\right) /$nitrate $\left(\mathrm{NO}_{3}{ }^{-}\right)$en oxyde nitrate réductase, eaux estuariennes, qualité de l'eau, oxyde d'azote nitreux $\left(\mathrm{N}_{2} \mathrm{O}\right)$ /molécule d'azote $\left(\mathrm{N}_{2}\right)$ jouent un rôle important dans la gestion de la qualité de l'eau. L'objectif de cet article est d'explorer le rôle des enzymes extracellulaires dans le cycle de l'azote $(\mathrm{N})$ des écosystèmes aquatiques. II apparaît que l'azote dans les estuaires, les marais salants, etc., ne reste pas assez longtemps pour être biodisponible, créant ainsi des conditions limitantes en azote. Cette étude montre que la nitrate réductase extracellulaire indigène avec d'autres enzymes impliquées dans les transformations de l'azote dans les sédiments et les eaux de systèmes estuariens peut causer une disparition de $\mathrm{NH}_{4}{ }^{+}$et $\mathrm{NO}_{3}{ }^{-}$des eaux et du $\mathrm{NH}_{4}{ }^{+}$et du $\mathrm{NO}_{3}{ }^{-}$des sédiments. Les résultats indiquent qu'en raison des activités extracellulaires en nitrate réductase et autres enzymes associées aux transformations de l'azote, une quantité importante de $\mathrm{NH}_{4}{ }^{+}$et $\mathrm{NO}_{3}{ }^{-}$peut rapidement quitter les systèmes sous forme de $\mathrm{N}_{2} \mathrm{O}$ et/ou d'oxyde nitrique (NO), 
créant des conditions limites en $\mathrm{N}$ dans les systèmes estuariens. De telles activités de nitrate réductase indigène sont utiles en supprimant l'azote biodisponible des systèmes, évitant ainsi des conditions eutrophes. Toutefois ces enzymes contribuent à l'augmentation de $\mathrm{N}_{2} \mathrm{O}$ dans l'atmosphère, gaz à effet de serre à fort potentiel de réchauffement (GWP) de 296.

\section{INTRODUCTION}

The rate-limiting steps in the mineralization of organic matter could be enzyme-induced hydrolysis of macromolecules (Keyhani and Roseman, 1997; Foreman et al., 1998; Grossart et al., 1998). Enzymes mediate a wide variety of biogeochemical chemical reactions, and have been linked to nutrients cycling in soils/sediments (Burns, 1986; Pant and Warman, 2000; Furlan and Pant, 2006) and aquatic systems (Pant et al., 2002).

The stability of enzymes can be increased by immobilization on a suitable solid support (Warman and Isnor, 1990; Pant and Warman, 2000). The immobilized enzyme may be used to catalyze the degradation of organic matter into plant available forms (Warman and Isnor, 1990) and to detoxify xenobiotics in polluted soils and waters. Regardless of the mechanisms of stabilization, enzymes immobilized in clay particles and humic colloids have been observed in soils and sediment with stable activity (Stevenson, 1986). Moreover, a large proportion of the total enzymic activity in soil may be produced by stable enzymes, which are independent of the activity associated with plant or microbial cells (Perez-Mateos and Rad, 1989).

Denitrification is a major anaerobic dissimilative pathway causing the loss of fixed- $\mathrm{N}$ from the environment, as well as removal of nitrate from surface waters and wastewaters. Nitrate is used as an electron acceptor for anaerobic respiration to generate energy. The reduction of $\mathrm{NO}_{3}{ }^{-}$to nitrite $\left(\mathrm{NO}_{2}^{-}\right)$is the first step of denitrification. Thereafter, $\mathrm{NO}_{2}{ }^{-}$can either be reduced to $\mathrm{NH}_{3}$ or sequentially reduced to $\mathrm{NO}, \mathrm{N}_{2} \mathrm{O}$ and $\mathrm{N}_{2}$; the synthesis of enzyme involved in each step is suppressed by $\mathrm{O}_{2}$ (Simon, 1988). At each reductive step, the gaseous product could either be released into the atmosphere, mostly however, the gas may go through the complete reduction to $\mathrm{N}_{2}$. Moreover, $\mathrm{NO}_{3}{ }^{-}$could go through assimilative reduction to $\mathrm{NH}_{3}$. When reduced to $\mathrm{NH}_{3}$, the $\mathrm{N}$ is transformed into a relatively less mobile form, preventing leaching of $\mathrm{NO}_{3}{ }^{-}$to aquifers. Denitrification to $\mathrm{N}_{2} \mathrm{O}$ though could contribute to increase in greenhouse gases. The dissimilatory nitrate reductases mediate the reduction of $\mathrm{NO}_{3}^{-}$to nitrite $\left(\mathrm{NO}_{2}^{-}\right)$in denitrifying bacteria, and bacteria dissimilating nitrate to ammonia.

The proliferation of microorganisms is affected by the abundance of organic matter. The effects of acid deposition on nutrient cycling are pronounced in sediments and waters. Not only is microbial activity $\mathrm{pH}$ dependent, most of the enzymes produced by microorganisms and plants have either acidic or alkaline $\mathrm{pH}$ optima. Moreover, the ionic state of enzymes is influenced by $\mathrm{pH}$ both directly on the functional groups of the active site and on the physical and chemical state of the enzyme-substrate and enzyme-product complexes.

Moreover, the rate of chemical reaction follows the Arrhenius theory, i.e., it depends on temperature. Enzyme catalyzed reactions are no exceptions to the Arrhenius theory. Mineralization and immobilization of nutrients such as $\mathrm{N}$ and $\mathrm{P}$ in waters and soils/sediments are strongly influenced by temperature (Pant et al., 2002). As the mineralization of detrital material proceeds, associated nutrients including $\mathrm{N}$ and $\mathrm{P}$ may release and transport to the water column. Several studies on decompositions of organic matter in sediments reported that aerobic decomposition could be faster (Lee, 1992) or slower (Sun et al., 1993). Soil/sediment microorganisms mineralize organic $P$ through the secretion of various phosphatases (Juma and Tabatabai, 1977; Pant et al., 2002). Similarly, plants can utilize organic $P$ fractions in soils by means of phosphatase activity (Pant et al., 1994a, 1994b; Furlan and Pant, 2006). Different types of phosphatases (phosphomonoesterase and phosphodiesterase) are reported to occur in soils/sediments both in soluble and immobilized forms (Burns, 1986; Boyd and Mortland, 1990; Pant and Warman, 2000). Similarly, several enzymes catalyzing the $N$ transformation in surface waters and sediments are known to occur, however, their collective roles 
as catalysts in hydrolyzing organic matter are not well understood. Considerable amounts of $\mathrm{N}_{2} \mathrm{O}$ gas are emitted from natural and cultivated soils through microbial processes, the most important being nitrification and denitrification (Xing, 1998). However, marshes and coastal waters could release substantial amount of $\mathrm{N}_{2} \mathrm{O}$ to the atmosphere, too.

Nitrogen enrichment of coastal waters is one of the most pervasive agents of change in the structure and function of coastal aquatic communities (Nixon et al., 1986; Valiela et al., 1990). As land-derived $\mathrm{N}$ loading in estuarine waters increases, chlorophyll concentrations in the water also increase. Such changes have been reported worldwide, as a result of human activities, such as increased urbanization, deforestation and agriculture (Valiela, 1995).

Recently developed global $\mathrm{N}$ budgets indicate that sedimentary denitrification removes from 95 to $300 \mathrm{Tg} \cdot \mathrm{yr}^{-1}$ of fixed $\mathrm{N}$ from the oceans. It has also been argued that the $\mathrm{N}$ isotope balance in the oceans requires the sedimentary denitrification to be two to three times the magnitude of the water column denitrification. This makes sedimentary denitrification the most important single sink for the oceanic $\mathrm{NO}_{3}{ }^{-}$, however, a large uncertainty in the magnitude of this sink remains (Gandy and Yoch, 1998).

The nitrification and denitrification processes in surface waters are a critical steps for the internal cycling of $\mathrm{N}$ in aquatic systems, and to a large degree, may determine the productivity and water quality of the ecosystem. Conversion of complex organic molecules to simpler organic and inorganic constituents by various processes such as abiotic leaching (Harrison and Mann, 1975; Benner et al., 1985), fragmentation (Boulton and Boon, 1991), extracellular enzymatic hydrolysis (Cunningham and Wetzel, 1989), and aerobic and anaerobic catabolic activities of microorganisms could occur depending on environmental conditions, and export or recycle through the ecosystems. Learning the resilience and threshold levels allows to gauge the strengths and weaknesses of our technological advancement and policies to tackle adversities of hydro-climatic changes to many ecosystems including aquatic and semi-aquatic ones. Thus, this study was conducted to determine the indigenous $\mathrm{N}$-reductase activity in sediments and surface waters of coastal/estuarine systems, and to estimate the potential removal of $\mathrm{N}$.

\section{MATERIALS AND METHODS}

\section{> SITE DESCRIPTION}

According to Intergovernmental Panel on Climate Change (IPCC, 1996), the North American average mean temperature could increase from $1-3{ }^{\circ} \mathrm{C}$ under a lower greenhouse gases emission case and up to $3.5-7.5^{\circ} \mathrm{C}$ in higher greenhouse gases emission case. Such rises in temperature may have unique region specific impacts. The Pelham Bay Park, Bronx, NY $\left(73^{\circ} 47^{\prime} \mathrm{W}, 40^{\circ} 52^{\prime} \mathrm{N}\right)$, the largest park located in the northeast corner of the New York City, comprises freshwater wetlands, saltwater marshes/lagoon and coastal ecosystems along with others, including meadows, forests, and mixed shrubs, and encompasses 2764 acres (Figure 1). The Pelham Bay area is an important estuary location in New York City, which is connected to the Long Island Sound, an estuary. The surface waters and sediments samples were collected at Turtle cove, the Orchard Beach, the Lagoon, and the Eastchester Bay. Measuring the indigenous nitrate-reductase activities and estimating the potential denitrification not only provide insights on $\mathrm{N}$ availability for the algal blooms but also help to estimate the role of estuarine ecosystems in increasing $\mathrm{N}_{2} \mathrm{O}$, a potent greenhouse gas, in the atmosphere. Conducting the study at this particular location, which is an inextricably-linked aquatic and terrestrial environment, helps get insight on any abrupt or nonlinear response of $\mathrm{N}$ to climate change because of their site specific characteristics, including proximity to urban/suburban development. 

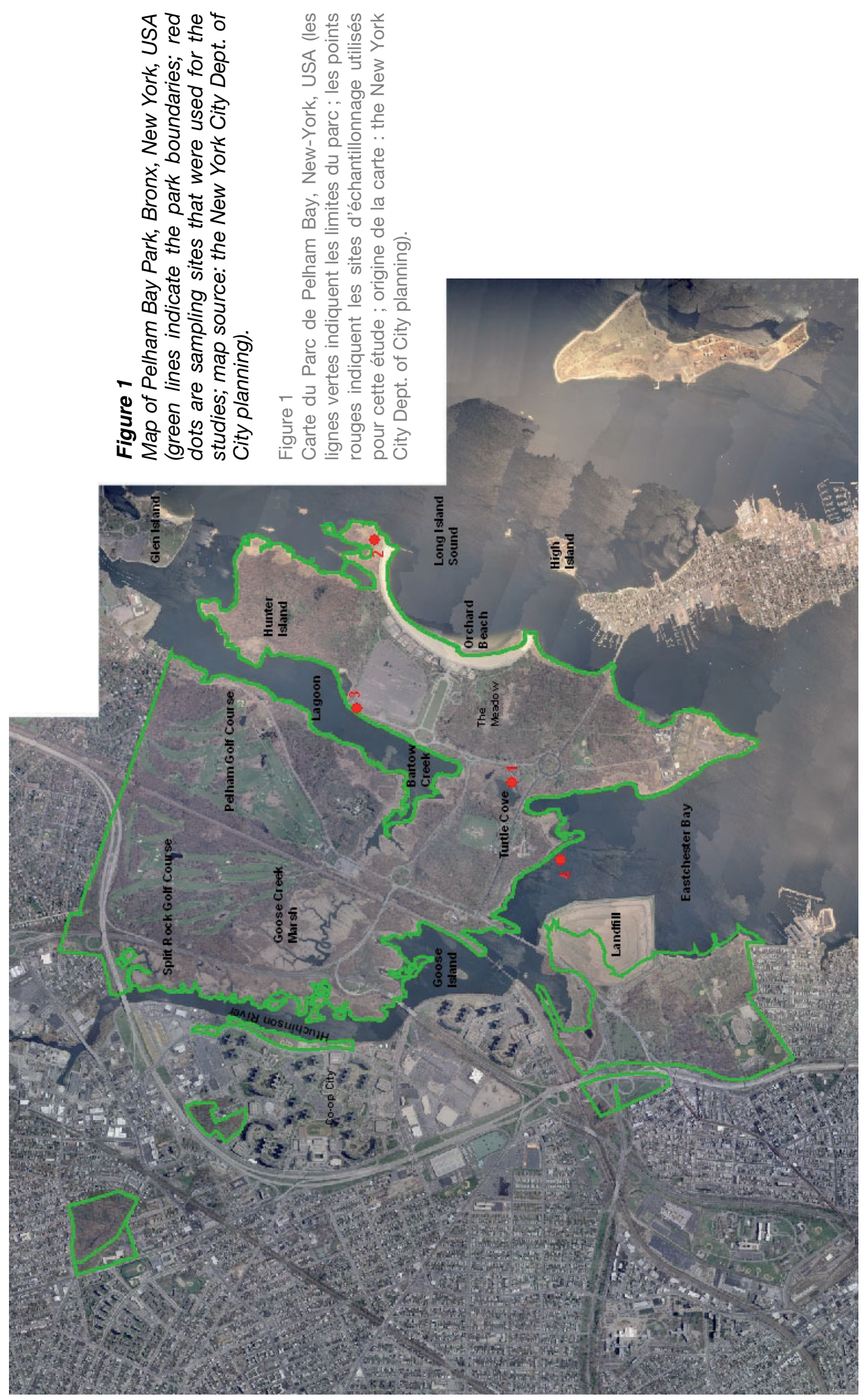


\section{> SAMPLING AND ANALYSIS}

Both the sediment and water samples were collected in the last week of May (early summer) and last week of August (late summer). Top-sediments $(0-10 \mathrm{~cm})$ were collected at four representative locations (Figure 1), in shallow waters $(50-75 \mathrm{~cm})$ using a corer $(25 \mathrm{~cm} \mathrm{x}$ $10 \mathrm{~cm}$ ). The dissolved $\mathrm{O}_{2}$ contained in the water columns ranged from 4.5 to $6.7 \mathrm{mg} \cdot \mathrm{L}^{-1}$, and temperatures of the waters were $19{ }^{\circ} \mathrm{C}$ and $25^{\circ} \mathrm{C}$, respectively, in early and late summer. A representative water sample was also collected at each location. The samples were delivered to the Environmental Research Laboratory, Department of Environmental, Geographic and Geological Sciences, Lehman College of the City University of New York in Ice-chests and stored at $4{ }^{\circ} \mathrm{C}$ until used for further experimentation. Since triplicate sediment samples were collected at each site to obtain a representative sample, sediment samples were homogenized prior to use for further analysis.

Estimations of $\mathrm{NO}_{3}{ }^{-}$in waters and sediment extracts $(2 \mathrm{M} \mathrm{KCl})$ were done using colorimetric method (Method 352.1; USEPA, 1993). Similarly, $\mathrm{NH}_{4}{ }^{+}$estimations in waters and sediment extracts $(2 \mathrm{M} \mathrm{KCl})$ were obtained using colorimetric method (Method 350.1; USEPA, 1993). Unless otherwise stated all the experiments were carried out in triplicates and means were reported. Data was analyzed by two-way analysis of variance (ANOVA) with SAS (SAS Institute Inc., 2002), and the mean comparisons were done by least significant difference (LSD) at the $P \leq 0.05$ level wherever necessary.

\section{> ENZYME INCUBATION}

Nitrate reductase (9029-27-0; obtained from MP Biomedicals Inc., Solon, OH, USA) was evaluated for its capacity to denitrification of $\mathrm{NO}_{3}{ }^{-}$in the surface waters and available $\mathrm{NO}_{3}{ }^{-}$ in sediments by batch incubation at $37{ }^{\circ} \mathrm{C}$ as described for phosphatases by (Juma and Tabatabai, 1977; Pant and Warman, 2000; Pant et al., 2002).

Unless otherwise stated, all the buffer solutions were prepared from tris- $\mathrm{HCl}$. The enzyme solution was prepared in $\mathrm{pH} 7.0$ buffer right before the experiment carried out to avoid loss in enzyme activity. The nitrate reductase solution contained 0.5 unit enzyme activity $\cdot \mathrm{mL}^{-1}$. To inhibit microbial activities during the incubation, $50 \mu \mathrm{L}$ of $5.2 \%$ sodium azide $\left(\mathrm{NaN}_{3}\right)$ solution was added (Pant et al., 2002) to the $15 \mathrm{~mL}$ triplicate samples (surface waters and sediment extracts) to yield a final concentration. Thereafter, $0.4 \mathrm{~mL}$ nitrate reductase solution was added to each vial, and incubated for $6 \mathrm{~h}$ at $37{ }^{\circ} \mathrm{C}$. The activity of enzyme required for individual incubation was pre-determined by measuring the $\mathrm{NO}_{3}{ }^{-}$concentration in the samples, and adding the sufficient unit of enzyme. For the controls, $15 \mathrm{~mL}$ samples were

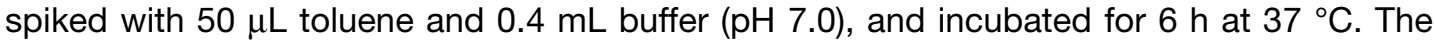
reduction in $\mathrm{NO}_{3}{ }^{-}$levels in the incubated samples during the 6-hour incubation with and without the added enzyme was considered as denitrification caused by added nitrate reductase and indigenous nitrate reductase, respectively, representing potential denitrification of $\mathrm{NO}_{3}{ }^{-}$in the estuarine systems. A similar set of the samples, but without added enzyme, were spiked with a small amount ( $6 \mu \mathrm{g}$; to avoid alteration in sample matrix) of $\mathrm{NH}_{4} \mathrm{NO}_{3}$ to determine potential nitrification capacity of indigenous enzymes. The loss of added and original $\mathrm{NH}_{4}{ }^{+}$in the samples was considered as the nitrification potential of the indigenous enzymes.

\section{RESULTS AND DISCUSSION}

\section{> NITRATE DYNAMIC IN SEDIMENTS AND SURFACE WATERS}

The $\mathrm{pH}$ of the water samples did not vary significantly among the sites, as well as there was no significant difference between the samples from early and late summer (all remain around neutral, 7.0-7.6). However, in samples collected during early summer, the $\mathrm{pH}$ of the sediments ranged from 7.7 for the Site 1 to 6.2 for the sediments from Site 3 . The $\mathrm{pH}$ of the sediments from Sites 4 and 2 were 6.4 and 7.1 , respectively. The $\mathrm{pH}$ of the sediment 


\section{Table I}

Selected chemical properties of the surface water and sediments samples; values with the same letter in a column for each sample type collected at the same location during different times are not significantly different; values denoted with "-" (hyphen) are negligible.

Tableau I

Propriétés chimiques des échantillons d'eau de surface et de sédiments ; les valeurs avec la même lettre dans une colonne pour chaque échantillon collecté au même site à différentes dates ne sont pas significativement différentes ; les valeurs notées par « - » (trait d'union) sont négligeables.

\begin{tabular}{|c|c|c|c|c|c|c|}
\hline \multirow{2}{*}{$\begin{array}{l}\text { Site } \\
\text { No. }\end{array}$} & \multirow[t]{2}{*}{ Locations } & \multirow[t]{2}{*}{ Sampled time } & \multicolumn{2}{|c|}{$\mathrm{NO}_{3}{ }^{-}$content } & \multicolumn{2}{|c|}{$\mathrm{NH}_{4}{ }^{+}$content } \\
\hline & & & $\begin{array}{l}\text { Surface water } \\
\left(\mathrm{mg} \cdot \mathrm{L}^{-1}\right)\end{array}$ & $\begin{array}{l}\text { Sediment } \\
\left(\mathrm{g} \cdot \mathrm{kg}^{-1}\right)\end{array}$ & $\begin{array}{c}\text { Surface water } \\
\left(\mathrm{mg} \cdot \mathrm{L}^{-1}\right)\end{array}$ & $\begin{array}{l}\text { Sediment } \\
\left(\mathrm{g} \cdot \mathrm{kg}^{-1}\right)\end{array}$ \\
\hline 1 & Turtle Cove & Early summer & $45.3^{b}$ & $3.41^{a}$ & 1.5 & 152 \\
\hline 2 & Orchard Beach & & $5.3^{b}$ & $2.50^{\mathrm{a}}$ & 0.1 & 0 \\
\hline 3 & Lagoon & & $8.7^{b}$ & $1.79^{\mathrm{b}}$ & 0.4 & 25.7 \\
\hline 4 & Eastchester Bay & & $152^{b}$ & $2.09^{a}$ & - & 7.0 \\
\hline & & Late summer & & & & \\
\hline 1 & Turtle Cove & & $251^{a}$ & $2.33^{b}$ & - & - \\
\hline 2 & Orchard Beach & & $251^{a}$ & $2.10^{b}$ & - & - \\
\hline 3 & Lagoon & & $211^{a}$ & $1.97^{\mathrm{ab}}$ & - & - \\
\hline 4 & Eastchester Bay & & $204^{a}$ & $1.92^{\mathrm{ab}}$ & - & - \\
\hline
\end{tabular}

samples collected in late summer, however, had relatively lower $\mathrm{pH}$, i.e., 5.7, 6.4, 6.1 and 6.4 for Sites 1,2, 3, and 4, respectively, perhaps, influencing the activities of indigenous enzymes involved in $\mathrm{N}$-transformations in sediments.

Extractable-nitrate content in sediments decreased comparatively overtime during the summer (Table I). The decrease in $\mathrm{NO}_{3}{ }^{-}$content in the sediments during the late summer was ranged from $31.67 \%$ at Site 1 to $16 \%$ at Site 2 and $8.13 \%$ at Site 4 . However, there was some increase $(10.05 \%)$ in sediment $\mathrm{NO}_{3}{ }^{-}$content during late summer at Site 3.

Unlike in sediments, however, the $\mathrm{NO}_{3}{ }^{-}$content in the surface waters increased several folds during the late summer compared to early summer ranging from 1.34 to 47.36 times (Table I). Compared to early summer, the $\mathrm{NO}_{3}^{-}$level in surface water during late summer was 47.36 times at Site 2 followed by 24.25 times at Site 3 and 5.54 times at Site 1 . However, the change in level of $\mathrm{NO}_{3}{ }^{-}$at Site 4 was at 1.34 fold. These data obtained for the water and sediment samples indicate that as the summer peaks, i.e., as the temperature rises, the storage of $\mathrm{NO}_{3}{ }^{-}$in sediments goes down while the availability of $\mathrm{NO}_{3}{ }^{-}$in the water columns, in general, drastically increases. This indicates that the availability of $\mathrm{NO}_{3}{ }^{-}$increases as the summer progresses and peaks during the late summer in the surface waters, in turn, may cause algal blooms since availability of $\mathrm{N}$ is considered as the limiting factor in saltwater/estuarine systems. However, the denitrification potential of $\mathrm{NO}_{3}{ }^{-}$in the surface waters (Figure 2) suggests that high indigenous nitrate-reductase activity may play an important role in removing $\mathrm{NO}_{3}{ }^{-}$from the algal availability pool and may cause increase in $\mathrm{N}_{2} \mathrm{O}$ in the atmosphere. High $\mathrm{NO}_{3}{ }^{-}$removals during summer or as the temperature increases have also been reported by various researchers (Cunningham and Wetzel, 1989; Touchette, 2007), indicating high $\mathrm{N}$ reductase activities during summer causing the loss of $\mathrm{NO}_{3}{ }^{-}$in the studied samples. Various $\mathrm{NO}_{3}{ }^{-}$reducing bacteria are found in marine sediments (Bonin, 1996), and high $\mathrm{NO}_{3}{ }^{-}$concentrations enhances denitrification. 


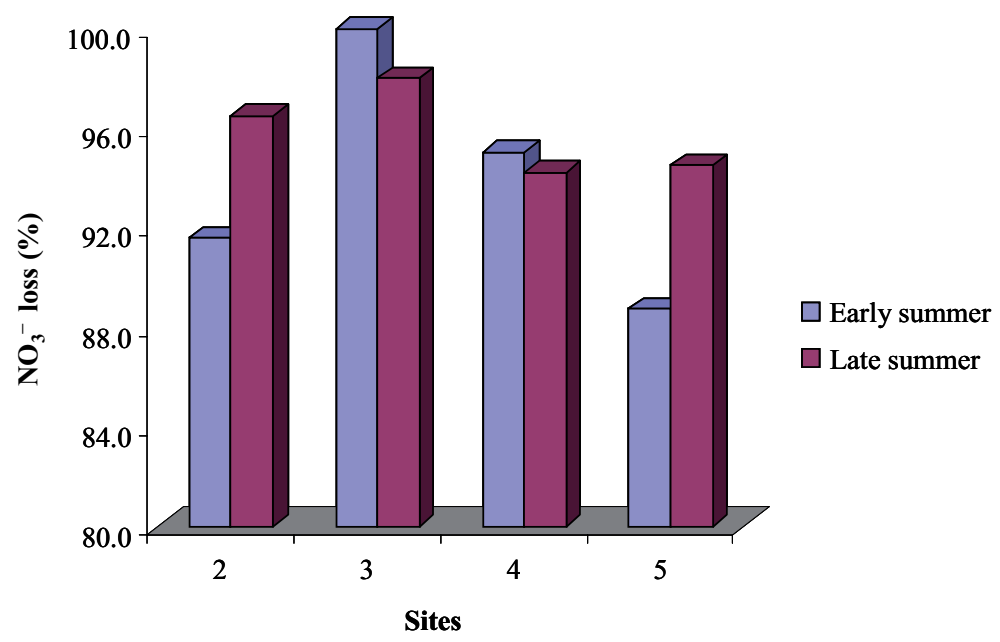

\section{Figure 2}

Potential denitrification in surface waters due to indigenous nitrate-reductase activities; errors are not shown but were $<5 \%$ of the mean $(\mathrm{n}=3)$.

\section{Figure 2}

Dénitrification potentielle dans les eaux de surface due aux activités nitrate-réductase ; les erreurs ne sont pas indiquées mais sont $<5 \%$ de la moyenne $(n=3)$.

\section{> NITRATE AND AMMONIUM LOSS FROM SURFACE WATERS AND SEDIMENTS}

It is apparent that both the water columns and sediments had very high indigenous nitratereductase activities (Figures 2 and 3 ). It is known that denitrification occurs in all rivers, lakes and coastal marine ecosystems, and its rate in estuarine/coastal sediments could range $50-250 \mu \mathrm{M} \mathrm{N} \cdot \mathrm{m}^{-2} \cdot \mathrm{h}^{-1}$ with extreme from 0 to $1067 \mu \mathrm{M} \mathrm{N} \cdot \mathrm{m}^{-2} \cdot \mathrm{h}^{-1}$ (Seitzinger, 1988). Moreover, Harrison (1973) reported nitrate reductase activity in estuarine surface waters over time in the range of $3.6-763 \mathrm{nM} \cdot \mathrm{L}^{-1} \cdot \mathrm{h}^{-1}$ (measured as nitrite formation), indicating high nitrate reductase activity could occur in estuarine systems. Since the samples contained very high indigenous nitrate-reductase activities, added nitrate-reductase was left with little amounts of substrates to be acted upon. Thus, added nitrate-reductase did not show more than $6 \%$ increase in the denitrification (i.e., substrate availability was scarce since most of the $\mathrm{NO}_{3}{ }^{-}$was acted upon by indigenous nitrate reductase). Heavy metals, such as $\mathrm{Cd}, \mathrm{Ni}$ and $\mathrm{Zn}$ are known to inhibit the $\mathrm{NO}_{3}{ }^{-}$reductase activities in algae (Tripathy et al., 2004; Awasthi, 2005). Since the sampled sites were in very close proximity to the urban land-uses, the possibility of having heavy metals, especially in sediments cannot be overlooked however, the samples had substantial native reductase activities, causing $\mathrm{NO}_{3}{ }^{-}$levels reduced drastically.

Similarly, complete loss of initial and added $\mathrm{NH}_{4}{ }^{+}(6 \mu \mathrm{g})$ to nitrification was observed in the surface waters due to indigenous enzymes suggesting existence of high activities of $\mathrm{N}$-transformation enzymes in the waters. Very high percentage (ranging from 99.6-99.9\%) of added $\mathrm{NH}_{4}{ }^{+}$was lost indicating surface waters possess the enough enzyme activities to remove substantial amount of increased $\mathrm{NH}_{4}{ }^{+}$from the bioavailable pool relatively quickly. These results may explain the reason for the $\mathrm{N}$ limited conditions in the category of studied ecosystem. The high potential activities of native reductases along with the others involved in the $\mathrm{N}$ transformations in the samples provides insights why the saltwater systems like coastal estuarine are usually $\mathrm{N}$-limited.

Thus, concluding that assimilatory $\mathrm{N}$ reduction is performed by a variety of bacteria and eukaryotes (Solomonson and Barber, 1990; Zvyagil'skaya et al., 1996), often mediated 


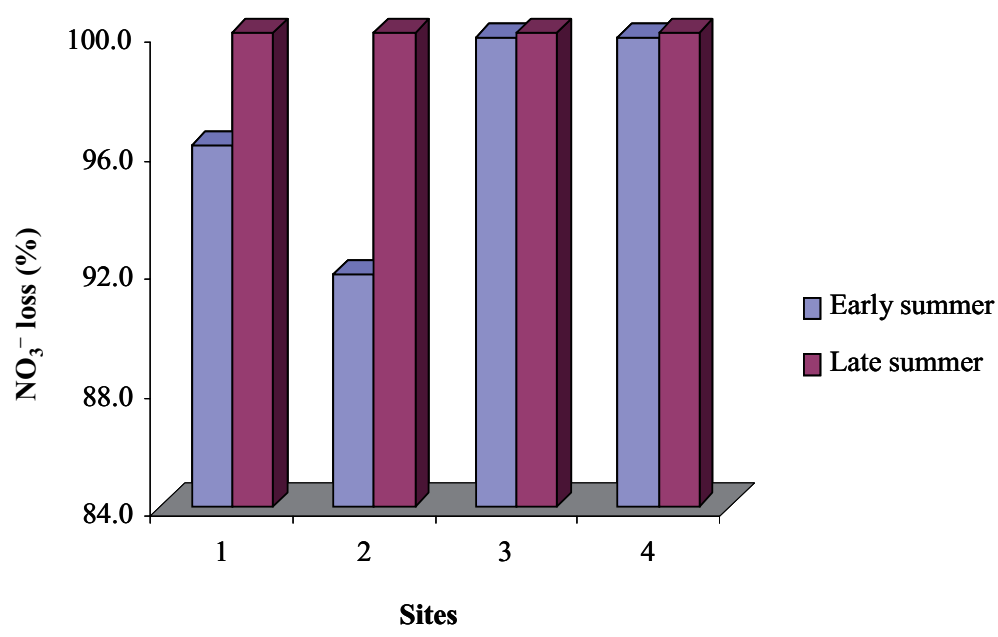

\section{Figure 3}

Potential denitrification of available $\mathrm{NO}_{3}{ }^{-}$in sediments due to indigenous nitratereductase activities; errors are not shown but were $<5 \%$ of the mean $(n=3)$.

\footnotetext{
Figure 3

Dénitrification potentielle du $\mathrm{NO}_{3}{ }^{-}$disponible dans les sédiments due aux activités nitrate réductase ; les erreurs ne sont pas indiquées mais sont $<5 \%$ de la moyenne $(n=3)$.
}

by $\mathrm{NO}_{3}{ }^{-}$and $\mathrm{NO}_{2}^{-}$reductases, for amino acids synthesis (Awasthi, 2005). It appears that, however, not by utilization of $\mathrm{N}$-species by biological communities, but due to released as $\mathrm{N}_{2} \mathrm{O}$ or $\mathrm{N}_{2}$ to the atmosphere because of the extracellular activities of enzymes involved in $\mathrm{N}$-tranformation including reductases. In these particular samples because the enzyme incubation studies were conducted under condition in which microbial activities were ceased, using toluene. It is known that a large proportion of enzymatic activity may be produced by extra-cellular stable (immobilized) enzymes that are independent of the activity associated with plants and microbial cells (Stevenson, 1986; Perez-Mateos and Rad, 1989). In other words, twist of fate, high activities of such enzymes are actually protecting the ecosystem from massive invasion of cyanobacterial communities. Such high activities of these enzymes, however, may contribute to increase in $\mathrm{N}_{2} \mathrm{O}$, an important greenhouse gas, which contributes to stratospheric ozone destruction and its global warming potential is about 296 times than that of $\mathrm{CO}_{2}$ in a 100-year time frame (IPCC, 1996), to the atmosphere. Also, elevated $\mathrm{NO}_{3}{ }^{-}$reductase activities at higher salinities are reported as high affinity $\mathrm{Na}^{+}$-dependent nutrient transport systems (for $\mathrm{NO}_{3}{ }^{-}, \mathrm{H}_{2} \mathrm{PO}_{4}{ }^{-}$and $\mathrm{HPO}_{4}{ }^{-}$) benefiting from the inwardly driving force for $\mathrm{Na}^{+}$in estuarine and coastal plants (Touchette, 2007). Similarly, $\mathrm{H}_{2} \mathrm{~S}$ may play a key role in regulating $\mathrm{N}_{2} \mathrm{O}$ production in eutrophic estuarine/coastal sediments by inhibiting activities of microbes, such as Aeromonas sps. and Vibrio sps. that are known to reduced $\mathrm{NO}_{3}{ }^{-}$to $\mathrm{N}_{2} \mathrm{O}$ (Senga et al., 2006).

Nitrate reductase plays a role in $\mathrm{NO}_{3}{ }^{-}$assimilation of plants, and some bacteria and fungi, as well as plant mediated denitrification could be responsible for the high $\mathrm{N}$ removal efficiency in constructed wetlands (Cottingham et al., 1999). Moreover, high nitrate reductase activity of roots than shoots observed in different submerged wetland plant species (Cedergreen and Madsen, 2003). Oxygen shortage induces root nitrate reductase activity even though the root $\mathrm{NO}_{3}{ }^{-}$reduction may depend on anaerobic metabolism of carbohydrates (Garcia-Novo and Crawford, 1973; de laHaba et al., 2001), or increases the relative importance of nitrate reductase activity in roots compared to a whole plant (Jiang and Hull, 1999).

Indeed, the $\mathrm{N}_{2} \mathrm{O}$ production has anthropogenic pathways such as agricultural and industrial processes, as well as biogenic pathways, e.g., nitrification/denitrification. The process by which molecular $\mathrm{N}$ in the atmosphere is reduced by bacteria and cyanobacteria to $\mathrm{NH}_{4}{ }^{+}$, 
and nitrification, the aerobic process where $\mathrm{NH}_{4}{ }^{+}$is oxidized first to $\mathrm{NO}_{2}{ }^{-}$, and is then further oxidized to $\mathrm{NO}_{3}{ }^{-}$, and denitrification, the process used by facultative anaerobic bacteria to oxidize organic matter using $\mathrm{NO}_{3}{ }^{-}$as a terminal electron acceptor with a byproduct of $\mathrm{N}_{2}$ or $\mathrm{N}_{2} \mathrm{O}$. Also, few studies (Smith and Zimmerman, 1981; Fazzolari et al., 1990; Senga et al., 2006) indicate that $\mathrm{N}_{2} \mathrm{O}$ is produced through dissimilatory $\mathrm{NO}_{3}{ }^{-}$reduction to $\mathrm{NH}_{4}{ }^{+}$. The current atmospheric concentration of $\mathrm{N}_{2} \mathrm{O}$ is about $310 \mathrm{ppb}$ (by volume), and it is increasing at a rate of $0.6-0.9 \mathrm{ppb} \cdot \mathrm{yr}^{-1}$ (Prinn et al., 1990). Since the factors regulating $\mathrm{N}_{2} \mathrm{O}$ accumulation is not well illustrated yet because of the simultaneous progression of the microbial pathways are complex in the ecosystems including estuarine and coastal waters and sediments, the possible pathways of removal of $\mathrm{NO}_{3}{ }^{-} / \mathrm{NH}_{4}{ }^{+}$from marshes/estuarine/coastal waters need further exploration.

\section{CONCLUSIONS}

The storage of $\mathrm{NO}_{3}{ }^{-}$in sediments deplete while the bioavailability of $\mathrm{NO}_{3}{ }^{-}$in the water columns substantially increases. This suggests that the availability of $\mathrm{NO}_{3}{ }^{-}$in the surface waters increases as the summer progresses and peaks during late summer, in turn, may cause algal blooms since availability of $\mathrm{N}$ is considered as the limiting factor in saltwater systems. However, the denitrification of $\mathrm{NO}_{3}{ }^{-}$in the surface waters may play an important role in removing $\mathrm{NO}_{3}{ }^{-}$from the algal availability pool and may cause release of $\mathrm{N}_{2} \mathrm{O}$ in the atmosphere. It is, indeed, indicative that both the surface waters and sediments potentially possess substantial activities of indigenous enzymes that are involved in denitrification and nitrification to quickly remove $\mathrm{NO}_{3}{ }^{-}$and $\mathrm{NH}_{4}{ }^{+}$from estuarine and marshes, and create $\mathrm{N}$-limited conditions. This may seem positively affecting the water quality of the systems, however, might add a significant amount of $\mathrm{N}_{2} \mathrm{O}$, a potent greenhouse gas, into the atmosphere. Estuaries are very dynamic systems, thus, sediment storage of $\mathrm{NO}_{3}{ }^{-}$may not be the mechanism affecting $\mathrm{NO}_{3}{ }^{-}$in the water columns. Moreover, external supply of nutrients including $\mathrm{N}$ could offset the loss of $\mathrm{NO}_{3}{ }^{-}$and keep the systems eutrophic, as well as other factors may control the algal growth. Further studies on factors controlling denitrification and nitrification in salt marshes, estuarine and coastal systems may help us to further our understandings on overall $\mathrm{N}$-cycling in the nature.

\section{ACKNOWLEDGEMENTS}

The author acknowledges the help from S. Huang and J. Wang, Department of Environmental, Geographic and Geological Sciences, Lehman College of the City University of New York, Bronx, NY, USA. The author is also grateful to M. Perron and T. Rho of City of New York Parks and Recreation, Bronx, NY, for their invaluable help. The invaluable comments/suggestions provided by the Chief Editor and reviewers are also greatly acknowledged. This work was partially supported by the Academic Affairs of the City University of New York, and Professional Staff Congress-the City University of New York.

\section{REFERENCES}

Awasthi M., 2005. Nitrate reductase activity: a solution to nitrate problems tested in free and immobilized algal cells in presence of heavy metals. Intl. J. Environ. Sci. Technol., 2, 201-206.

Benner R.M., Moran M.A. and Hodson R.E., 1985. Effects of pH and plant source on lignocellulose biodegradation rate in two wetland ecosystems, the Okeefenokee Swamp and a Georgia salt marsh. Limnol. Oceanogr., 30, 489-499.

Bonin P., 1996. Anaerobic nitrate reduction to ammonium in two strains isolated from coastal marine sediment: a dissimilatory pathway. FEMS Microbiol. Ecol., 19, 27-38. 
Boulton A.J. and Boon P.I., 1991. A review of methodology used to measure leaf litter decomposition lotic environments: Time to turn over an old leaf. Aust. J. Mar. Freshwat. Res., 42, 1-43.

Boyd S.A. and Mortland M.M., 1990. Enzyme interactions with clays and clay-organic matter complexes. In: Bollag J.M. and Stotzky G. (eds.), Soil Biochemistry, 6, Marcel Dekker, New York, USA, 1-28.

Burns R.G., 1986. Interactions of enzymes with soil mineral and organic colloids. In: Huang P.M. and Schnitzer M. (eds.), Interactions of soil minerals with natural organics and microbes, Special Publication, Soil Science Society of America, Inc. (17), Madison, USA, 423-427.

Cedergreen N. and Madsen T.V., 2003. Nitrate reductase activity in roots and shoots of aquatic macrophytes. Aquat. Bot., 76, 203-212.

Cottingham P.D., Davis T.H. and Hart B.T., 1999. Aeration to promote nitrification in constructed wetlands. Environ. Technol., 20, 69-75.

Cunningham H.W. and Wetzel R.G., 1989. Kinetic analysis of protein degradation by a freshwater wetland sediment community. Appl. Environ. Microbiol., 56, 1963-1976.

de laHaba P., Aguera E., Benitez L. and Maldonado J.M., 2001. Modulation of nitrate reductase activity in cucumber (Cucumis sativus) roots. Plant Sci., 161, 231-237.

Fazzolari E., Mariotti A. and Germon J.C., 1990. Nitrate reduction to ammonia: a dissimilatory process in Enterobactor amnigenus. Can. J. Microbiol., 36, 779-785.

Foreman C.M., Franchini P. and Sinsabaugh R.L., 1998. The trophic dynamics of riverine bacterioplankton: Relationships among substrate availability, ectoenzyme kinetics, and growth. Limnol. Oceanogr., 43, 1344-1352.

Furlan S.A. and Pant H.K., 2006. General properties of enzymes. In: Pandey A., Webb C. and Larroche C. (eds.), Enzyme Technology, Springer Verlag/Asiatech Publishers, Inc., 11-35.

Gandy E.L. and Yoch D.C., 1998. Relationship between nitrogen-fixing sulfate reducers and fermenters in salt marsh sediments and roots of Spartina alterniflora. Appl. Environ. Microbiol., 64, 2031-2036.

Garcia-Novo F. and Crawford R.M.M., 1973. Soil aeration, nitrate reduction and flooding tolerance in higher plants. New Phytol., 72, 1031-1039.

Grossart H.P., Berman T., Simon M. and Pohlmann K., 1998. Occurrence and microbial dynamics of macroscopic organic aggregates (lake snow) in Lake Kinneret, Israel, in fall. Aquat. Microb. Ecol., 14, 59-67.

Harrison P.G. and Mann K.H., 1975. Detritus formation from eelgrass (Zostera marina L.): The relative effects of fragmentation, leaching, and decay. Limnol. Oceanogr., 20, 924-934.

Harrison W.G., 1973. Nitrate reductase activity during a dinoflagellate bloom. Limnol. Oceanogr., 18, 457-465.

IPCC (Intergovernmental Panel on Climate Change), 1996. Climate change 1995: The science of climate change. In: Houghton J.T., Melra Filho L.G., Collander B.A., Harris N., Kattenberg A. and Maskell K. (eds.), Cambridge University Press, Cambridge, UK.

Jiang Z.C. and Hull R.J., 1999. Partitioning of nitrate assimilation between shoots and roots of Kentucky bluegrass. Crop Sci., 39, 746-754.

Juma N.G. and Tabatabai M.A., 1977. Distribution of phosphomonoesterases in soils. Soil Sci., 126, 101-108.

Keyhani N.O. and Roseman S., 1997. Physiological aspects of chitin catabolism in marine bacteria. Biochim. Biophys. Acta (G), 1473, 108-122.

Lee C., 1992. Controls on organic-carbon preservation - the use of stratified water bodies to compare intrinsic rates of decomposition in oxic and anoxic systems. Geochim. Cosmochim. Acta, 56, 3323-3335.

Nixon S.W., Oviatt C.A., Frithsen J. and Sullivan B., 1986. Nutrients and the productivity of estuarine and coastal marine environments. J. Limnol. Soc. South Africa, 12, 43-71.

Pant H.K. and Warman P.R., 2000. Enzymatic hydrolysis of soil organic phosphorus by immobilized phosphatases. Biol. Fertil. Soils, 30, 306-311.

Pant H.K., Edwards A.C. and Vaughan D., 1994a. Extraction, molecular fractionation and enzyme degradation of organically associated phosphorus in soil solutions. Biol. Fertil. Soils, 17, 196-200.

Pant H.K., Vaughan D. and Edwards A.C., 1994b. Molecular size distribution and enzymatic degradation of organic phosphorus in root exudates of spring barley. Biol. Fertil. Soils, 18, 285-290.

Pant H.K., Reddy K.R. and Dierberg F.E., 2002. Bioavailability of organic phosphorus in a submerged aquatic vegetation-dominated treatment wetland. J. Environ. Qual., 31, 1748-1756.

Perez-Mateos M. and Rad J.C., 1989. Immobilization of alkaline phosphatase by soil structural units. Biotech. Appl. Biochem., 11, 371-378. 
Prinn R., Cunnold D., Rasmussen R., Simmonds P., Alyea F., Crawford A., Fraser P. and Rosen R., 1990. Atmospheric emission and trends of nitrous oxide deduced from 10 years of Ale-Gauge data. J. Geophys. Res. D, Atmospheres, 95, 18360-18385.

SAS Institute, Inc., 2002. The SAS system for Windows, version 9.1, SAS Cary, N.C.

Seitzinger S.P., 1988. Denitrification in freshwater and coastal marine ecosystems: ecological and geochemical significance. Limnol. Oceanogr., 33, 702-724.

Senga Y., Mochida K., Fukumori R., Okamoto N. and Seike Y., 2006. $\mathrm{N}_{2} \mathrm{O}$ accumulation in estuarine and coastal sediments: the influence of $\mathrm{H}_{2} \mathrm{~S}$ on dissimilatory nitrate reduction. Estuar. Coastal Shelf Sci. , 67, 231-238.

Simon N.S., 1988. Nitrogen cycling between sediment and the shallow-water column in the transition zone of the Potomac River and estuary. 1. Nitrate and ammonium fluxes. Estuar. Coastal Shelf Sci., 28, 483-497.

Smith M.S. and Zimmerman K., 1981. Nitrous oxide production non-denitrifying. Soil Sci. Soc. Amer. J., 45, 865-871.

Solomonson L.P. and Barber M.J., 1990. Assimilatory nitrate reductase: functional properties and regulation. Plant Mol. Biol., 41, 225-253.

Stevenson F.J., 1986. Cycles of soil - Carbon Nitrogen, Phosphorous, Sulfur, Micronutrients, WileyInterscience.

Sun M.Y., Lee C. and Aller R.C., 1993. Anoxic and oxic degradation of C-14-labeled chloropigments and a C-14-labeled diatom in Long-Island Sound sediments. Limnol. Oceanogr., 57, 147-157.

Touchette B.W., 2007. Seagrass-salinity interactions: Physiological mechanisms used by submersed marine angiosperms for life at sea. J. Exptl. Marine Biol. Ecol., 350, 194-215.

Tripathi B.N., Mehta S.K. and Gaur J.P., 2004. Recovery of uptake and assimilation of nitrate in Scenedesmus sp. previously exposed to elevated levels of $\mathrm{Cu}^{2+}$ and $\mathrm{Zn}^{2+}$. J. Plant Physiol., 161, 543-549.

USEPA (U.S. Environmental Protection Agency), 1993. Methods of chemical analysis of water and wastes, Environ. Monit. Support Lab, Cincinnati, USA.

Valiela I., 1995. Marine Ecological Processes, Springer-Verlag, New York, USA.

Valiela I., Costa J., Foreman K., Teal J.M., Howes B. and Aubrey D., 1990. Transport of groundwaterborne nutrients from watersheds and their effect on coastal waters. Biogeochem., 10, 177-197.

Warman P.R. and Isnor R.A., 1990. Hydrolysis of low molecular weight soil peptides by immobilized proteases in column and batch reaction systems. Biol. Fertil. Soils, 9, 335-340.

Xing G.X., 1998. $\mathrm{N}_{2} \mathrm{O}$ emission from cropland in China. Nutr. Cycles Agroecosys., 52, 249-254.

Zvyagil'skaya R.A., Vartapetyan B.B. and L'vov N.P., 1996. Nitrate dissimilation in eukaryotes. Appl. Biochem. Microbiol., 32, 165-169. 